\title{
High performance liquid chromatography determination of cucurbitacins in the roots of Wilbrandia ebracteata Cogn.
}

\author{
Patricia Baier Krepsky, ${ }^{, 1}$ Mariana de Oliveira Cervelin, ${ }^{1}$ Débora Porath, ${ }^{1}$ \\ Rodrigo Rebelo Peters, ${ }^{2}$ Rosa Maria Ribeiro-do-Valle, ${ }^{2}$ Mareni Rocha Farias ${ }^{1}$
}

\author{
${ }^{1}$ Departamento de Ciências Farmacêuticas, Universidade Federal de Santa Catarina, Campus Universitário, \\ Trindade, 88040-900 Florianópolis-SC, Brazil \\ ${ }^{2}$ Departamento de Farmacologia, Universidade Federal de Santa Catarina, Rua Ferreira Lima, 82, \\ 88015-420 Florianópolis-SC, Brazil
}

\begin{abstract}
RESUMO: "Determinação de cucurbitacinas em raízes de Wilbrandia ebracteata Cogn. por cromatografia líquida de alta eficiência". Raízes de Wilbrandia ebracteata Cogn. (Cucurbitaceae), tradicionalmente empregada no tratamento de doenças reumáticas, contém cucurbitacinas, sendo di-hidrocucurbitacina B a mais abundante, enquanto cucurbitacina B está presente em menor quantidade. Foi desenvolvido um método para determinação quantitativa destas cucurbitacinas. Os parâmetros selecionados foram: eluente isocrático acetonitrila $/ \mathrm{H}_{2} 040: 60$, fluxo $1,2 \mathrm{~mL} / \mathrm{min}$. e detecção em $230 \mathrm{~nm}$. Diversas formas de preparo da amostra foram testadas, sendo que extração com diclorometano sob refluxo forneceu o melhor resultado. O processo de validação incluiu: linearidade, exatidão, repetibilidade e precisão intermediária. A curva de calibração para a di-

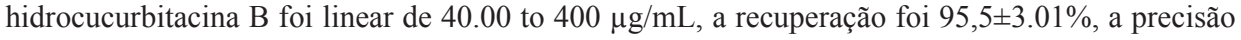
intermediária, $1,64 \%$ e a repetibilidade variou entre 1,30 a $2,05 \%$. A curva de calibração da cucurbitacina B foi linear de 4,00 to $240 \mu \mathrm{g} / \mathrm{mL}$, a recuperação encontrada foi igual a $96,6 \pm 2.45 \%$, a precisão intermediária, $2,29 \%$ e a repetibilidade variou entre 1,03 a 2,95\%. Análise do mesmo espécime de $W$. ebracteata uma vez por ano de 2002 a 2005 revelou grande aumento no teor de cucurbitacina $\mathrm{B}$ após a raiz ter sido atacada por herbívoro.
\end{abstract}

Unitermos: Wilbrandia ebracteata, Cucurbitaceae, cucurbitacina B, di-hidrocucurbitacina B, interação planta herbívoro, validação.

\begin{abstract}
Roots of Wilbrandia ebracteata Cogn., Cucurbitaceae, used in folk medicine for treatment of rheumatic disease, are rich in cucurbitacins. Dihydrocucurbitacin B is the most abundant cucurbitacin while cucurbitacin B is a minor component. A reverse-phase HPLC system was developed for simultaneous quantitative assay of these cucurbitacins in the roots. The optimised experimental conditions were acetonitrile $/ \mathrm{H}_{2} 040: 60$, flow-rate $1.2 \mathrm{~mL} / \mathrm{min}$., detection at $230 \mathrm{~nm}$ and isocratic elution. A variety of sample preparation modes were tested and the extraction with dichloromethane under reflux gave better results. The validation process included linearity, accuracy, repeatability and intermediate precision. The calibration curve of dihydrocucurbitacin B was linear from 40.00 to $400 \mu \mathrm{g} / \mathrm{mL}$, the recovery was $95.5 \pm 3.01 \%$, the intermediate precision was found to be $1.64 \%$ and the repeatability varied between 1.30 to $2.05 \%$. The calibration curve of cucurbitacin B was linear from 4.00 to $240 \mu \mathrm{g} / \mathrm{mL}$, intermediate precision was found to be $2.29 \%$ and repeatability varied between 1.03 to $2.95 \%$. Analysis of the same specimen of W. ebracteata every year from 2002 to 2005 revealed a great rise on the cucurbitacin B concentration after the root was attacked by an herbivore.
\end{abstract}

Keywords: Wilbrandia ebracteata, Cucurbitaceae, cucurbitacin B, dihydrocucurbitacin B, plantherbivore interaction, accuracy.

\section{INTRODUCTION}

Wilbrandia ebracteata Cogn., usually known as "Taiuiá" in Brazil, is a South American species from Cucurbitaceae family. The roots are commonly employed in folk medicine mainly for treatment of rheumatic disease (Corrêa, 1984, Simões et al., 1986). The antiinflammatory activity of the dichloromethanic fraction has been demonstrated (Peters et al., 1997; Peters et al., 1999), as well as the anti-ulcer activity of the leaves (González \& DiStasi, 2002) and absence of antitubercular activity (Pavan et al., 2009). Phytochemical studies of the roots 
led to the isolation of 23,24-dihydrocucurbitacins $\mathrm{B}$ and E, dihydroisocucurbitacin B, cucurbitacins B, D, E, G, H, $\mathrm{P}, \mathrm{R}, 22$-deoxycucurbitacin $\mathrm{D}$, and four new cucurbitacins (Farias et al., 1993, Schenkel et al., 1992).

It has been previously demonstrated that the dichloromethanic fraction from $W$. ebracteata decreases carrageenan-induced paw edema in rats and reduces formalin-induced hyperalgesia and acetic acid-induced abdominal writhing in mice (Peters et al., 1997). This fraction decreases cellular migration, exsudate formation and inhibits prostaglandin E2 release (Peters et al., 1999). The oral treatment of the animals with the dichloromethanic fraction produced a significant reduction of articular incapacitation; reduced nitrite release into the zymosaninflamed joints, selectively inhibit COX-2 activity observed in vitro experiments. The effects could be, at least in part, attributed to cucurbitacins since several of these were isolated from this fraction (Peters et al., 2003) and dihydrocucurbitacin $\mathrm{B}$ presented in vitro and in vivo anti-inflammatory affect (Siqueira et al., 2007).

Some studies report cucurbitacin analysis by HPLC (Bauer et al., 1985; Stuppner \& Wagner, 1992; Halaweish \& Tallamy, 1993; Matsuo et al., 1999; Sturm \& Stuppner, 2000), but none of them was applied to $W$. ebracteata analysis. Development of quantitative method for cucurbitacin analysis can contribute to the standardisation and quality control of the drug as well as its extracts. This control is important to guarantee safety and efficacy in the use of any pharmaceutical product, including medicinal plants. In this regard, we have developed a HPLC method with an optimised extraction procedure for the quantification of the major constituent dihydrocucurbitacin B and cucurbitacin B from roots of $W$. ebracteata.

\section{MATERIAL AND METHODS}

\section{Apparatus and solvents}

The analyses were carried out in a Shimadzu liquid chromatograph (model VP). Two pumps, a C-18 reverse-phase column (Supelco ${ }^{\circledR}, 150$ X $4.6 \mathrm{~mm}, 5 \mu \mathrm{m}$ ) and a C-18 preparative reverse-phase column (Shimadzu ${ }^{\circledR}$, ODS, PREP-ODS, 20 X $250 \mathrm{~mm}$ ) were used. Detection was performed with an ultraviolet spectrometric detector. Injection volume was $20 \mu \mathrm{l}$ (analytical column) or 1 $\mathrm{mL}$ (preparative column). The columns were used at a controlled ambient temperature $\left(18-20{ }^{\circ} \mathrm{C}\right)$. Solvents: acetonitrile HPLC/UV grade $\left(\operatorname{Vetec}^{\circledR}\right)$, water purified by a MilliQ system (Millipore ${ }^{\circledR}$ ) and petroleum ether $\left(\right.$ Nuclear $\left.^{\circledR}\right)$. Solvents used in the extract preparation were dichloromethane $\left(\right.$ Nuclear $\left.^{\circledR}\right)$ analytical grade and methanol HPLC/UV grade $\left(\right.$ Vetec $\left.^{\circledR}\right)$.

\section{Plant materials}

For isolation of dihydrocucurbitacin B underground parts of Wilbrandia ebracteata Cogn. were collected in Nova Petrópolis-RS, Brazil and identified by Professor Dr. Sérgio Bordignon (Department of Botany, Universidade de Pelotas, RS, Brazil) and Professor Dr. Eloir Paulo Schenkel (Universidade Federal de Santa Catarina). Voucher specimens were deposited in the herbarium of the Faculty of Pharmacy (Universidade Federal do Rio Grande do Sul, Porto Alegre, Brazil). Fruits of Luffa operculata acquired at a local market were employed to isolation from cucurbitacin B. They were identified by comparing their botanical characteristics with the literature (Oliveira, 1991; Brock et al., 2003). For quantitative analysis the root of a single specimen of $W$. ebracteata grown in FlorianópolisSC, Brazil was used. That specimen was identified by comparing their botanical and chemical (HPLC analysis) characteristics to the authentical sample.

\section{Dihydrocucurbitacin B isolation}

Cut, air-dried roots of $W$. ebracteata were extracted at room temperature methanol. The methanol was dried under reduced pressure and the residue was suspended in water. This suspension was successively extracted with petroleum ether and dichloromethane. The dried dichloromethanic fraction was chromatographed on a column with silica gel $60(0.063-0.200 \mathrm{~mm})$ by gradient elution (petroleum ether/ethyl acetate 1:2). The final purification was carried out by preparative high performance liquid chromatography $\left(\mathrm{CH}_{3} \mathrm{CN} / \mathrm{H}_{2} \mathrm{O} 42: 58\right.$, flow-rate $6.0 \mathrm{~mL} / \mathrm{min}$., $230 \mathrm{~nm}$ ). The major compound was identified by thin layer chromatography, ultraviolet absorption spectrum $(0.1 \mathrm{mg} / \mathrm{mL})$ and NMR, the spectra being compared with the available literature (Farias et al., 1993).

\section{Cucurbitacin B isolation}

Fruits of $L$. operculata were extracted at room temperature with commercial ethanol (95\%). The ethanol was concentrated under reduced pressure and the residue was suspended in water. This suspension was successively extracted with petroleum ether and dichloromethane. The concentrated dichloromethanic fraction was chromatographed on a column with silica gel 60 (0.063$0.200 \mathrm{~mm}$ ) and dichloromethane as the mobile phase. The final purification was carried out by preparative high performance liquid chromatography $\left(\mathrm{CH}_{3} \mathrm{CN} / \mathrm{H}_{2} \mathrm{O} 42: 58\right.$, flow-rate $6.0 \mathrm{~mL} / \mathrm{min} ., 230 \mathrm{~nm}$ ). The major compound was identified by ultraviolet absorption $(0.1 \mathrm{mg} / \mathrm{mL})$, thin layer chromatography and NMR, the spectra being compared with the available literature (Farias et al., 1993). 


\section{Purity of marker compounds}

Solution of dihydrocucurbitacin B $(400 \mu \mathrm{g} / \mathrm{mL})$ and cucurbitacin $\mathrm{B}(0.4 \mathrm{\gamma g} / \mathrm{mL})$ were analysed $\left(\mathrm{CH}_{3} \mathrm{CN} /\right.$ $\mathrm{H}_{2} \mathrm{O} 40: 60$, flow-rate $1.2 \mathrm{~mL} / \mathrm{min}$., 210 and $\left.230 \mathrm{~nm}\right)$. The purity was determinated by the relative percentage of the substances. The impurities presented the same ultraviolet spectrum as the main compound.

\section{Optimisation of the analysis parameters}

The variables tested were: composition of the eluent $\left(\mathrm{CH}_{3} \mathrm{CN} / \mathrm{H}_{2} \mathrm{O} 40: 60,44: 56,48: 52\right)$, flow-rate (1.0; $1.2 ; 1.4 \mathrm{~mL} / \mathrm{min}$.$) , wavelength (210$ and $230 \mathrm{~nm})$, and elution (isocratic or gradient elution). A solution (1 mg/ $\mathrm{mL}$ ) of dichloromethanic fraction (see dihydrocucurbitacin $\mathrm{B}$ isolation) was used in these tests.

\section{Optimisation of the sample preparation method}

The following procedures were tested: maceration with ethanol followed by partitioning with petroleum ether and dichloromethane; maceration with petroleum ether, followed by maceration or reflux with dichloromethane; reflux with methanol $(2 \times 40$ and $2 \times 20 \mathrm{~mL})$; reflux with dichloromethane $(2 \times 20 \mathrm{~mL}$ and $2 \times 40 \mathrm{~mL})$. Different granulometry $(180,355 \mu \mathrm{m})$ and amount of powdered roots $(0.5$ and $1.0 \mathrm{~g})$ were also tested. The results obtained with all methods were compared on the basis of standard deviation, the variation coefficient and the area under the curve.

\section{Selected sample preparation method}

The $1.00 \mathrm{~g}$ of the roots $(180 \mu \mathrm{m})$ was extracted with $20.0 \mathrm{~mL}$ of dichloromethane under reflux for $10 \mathrm{~min}$. The extract was cooled to room temperature and filtered through filter paper to a $50 \mathrm{~mL}$ round flask. The residue was extracted under reflux with another $20 \mathrm{~mL}$ dichloromethane for $10 \mathrm{~min}$. The combined filtered extracts was dried under reduced pressure and transferred with methanol to a volumetric flask $(10 \mathrm{~mL})$. The methanolic extract was filtered through a membrane $(0.45 \mu \mathrm{m})$ before injection.

\section{Calculation}

The results of the quantification assay by HPLC were expressed in $\mathrm{mg} / 100 \mathrm{~g}$ of dried $W$. ebracteata roots. The external standard method was used. The calculation was performed using regression equations. All experiments were performed in triplicate and the results are expressed as mean $\pm \mathrm{SD}$.

\section{Peak identification and peak purity}

Marker compound peaks were identified by comparing the retention time of these peaks in the extract with those of the isolated compounds (dihydrocucurbitacin $\mathrm{B}$ and cucurbitacin B). The purity of the peak was confirmed by extracting the ultraviolet peaks corresponding to the marked compounds.

\section{Stability of marker compounds}

The stability was evaluated through the triplicate analysis of the stock solutions of dihydrocucurbitacin B and cucurbitacin B on six consecutive days. Variance analysis $(\alpha=0.01)$ was applied in the comparison of the area under the curve data.

\section{Linearity}

Stock solutions from dihydrocucurbitacin B (0.40 $\mathrm{mg} / \mathrm{mL})$ and cucurbitacin $\mathrm{B}(0.40 \mathrm{mg} / \mathrm{mL})$ were prepared in methanol. Five dilutions of dihydrocucurbitacin B (40.0, $80.0,120,240,400 \mu \mathrm{g} / \mathrm{mL})$ and cucurbitacin B (4.00, $40.0,80.0,120,240 \mu \mathrm{g} / \mathrm{mL}$ ) were prepared and subjected to HPLC analyses. The solutions were analysed at 230 nm (United States Pharmacopeia, 1995; International Conference on Harmonisation, 1996).

\section{Recovery}

The recovery percentage was used to determine the accuracy. Marker compounds were added separately to the powdered plant material before extraction. A $400 \mu \mathrm{g} /$ $\mathrm{mL}$ solution $(1.00 \mathrm{~mL})$ of dihydrocucurbitacin $\mathrm{B}$ was added to a sample of $W$. ebracteata root (1.00 g). This procedure was repeated three times ( $400 \mu \mathrm{g}$ to each sample of roots). Cucurbitacin B $(19.4 \mu \mathrm{g} / \mathrm{mL})$ was added to other three samples (19.4 $\mu \mathrm{g}$ to each sample of roots). The amount of marker compound added corresponds to approximately $100 \%$ of the plant content previously determined by the developed method. The results were expressed as recovered percentage (United States Pharmacopeia, 1995; International Conference on Harmonisation, 1996).

\section{Repeatability and intermediate precision}

A sample of $W$. ebracteata root $(180 \mu \mathrm{m})$ was analysed for six consecutive days in triplicate. The sample was prepared and analysed daily in agreement with the developed methods. The experimental conditions - temperature, analyst, equipment, reagents and analysis parameters - were maintained constant. The repeatability was assessed by the range of the variation coefficients (United States Pharmacopeia, 1995; International Conference on Harmonisation, 1996).

\section{Annual analysis}

The developed method was applied in the analysis 
of the same specimen of Wilbrandia ebracteata grown in Florianópolis. A part of the root was collected annually (2002 - 2005). Each sample was analysed in triplicate by the HPLC method for simultaneous quantitative assay of dihydrocucurbitacin B and cucurbitacin B.

\section{RESULTS AND DISCUSSION}

The analysis parameters were chosen according to the peak resolution and the analysis time. Acetonitrile/ water 40:60, flow-rate of $1.2 \mathrm{~mL} / \mathrm{min}$, detection at 230 $\mathrm{nm}$ and isocratic elution were chosen. The gradient elution offered better resolution, however, the isocratic elution required a shorter stabilisation time between the applications and better baseline.

In medicinal plant analysis the sample preparation is a crucial step. The extraction with ethanol followed by partitioning with petroleum ether and dichloromethane demanded longer time and gave low precision according to the high variation coefficient. Maceration with petroleum ether followed by maceration with dichloromethane and reflux with methanol showed low extraction capacity of cucurbitacins. Reflux with dichloromethane proved to be more precise, faster and ensured better extraction.

Analyses of dihydrocucurbitacin B $(0.4 \mu \mathrm{g} / \mathrm{mL})$ and cucurbitacin B $(0.4 \mu \mathrm{g} / \mathrm{mL})$ solutions demonstrated purity over $95 \%$. The solutions were stable under refrigeration (about $7^{\circ} \mathrm{C}$ ) for at least six days sinceintegrated peak area for a six-day period did not present significant variation $(\alpha=0.01)$ in the variance analysis. Calibration curve from dihydrocucurbitacin B and cucurbitacin B gave correlation coefficient $\left(R^{2}\right)=0.9998$ and 0.9997 , respectively. The $\mathrm{y}$-intercepts were close to zero. The regression equation was $y=23.5 x-0.0531$ for cucurbitacin $\mathrm{B}$ and $\mathrm{y}=1.82 \mathrm{x}+0.00260$ for dihydrocucurbitacin $\mathrm{B}$.

The recovery was $95.5 \pm 3.01 \%$ for dihydrocucurbitacin B and $96.6 \pm 2.45 \%$ for cucurbitacin B. A mean variation coefficient of $1.64 \%$ was obtained for the concentration of dihydrocucurbitacin B obtained in triplicate analyses over six days (intermediate precision). In the same test variation coefficient ranged between 1.35 to $2.05 \%$ (repeatability). Cucurbitacin B analyses resulted in an intermediate precision of $2.42 \%$ and repeatability varying between 1.03 to $2.95 \%$. The concentrations observed were $45.2 \pm 0.8 \mathrm{mg}$ dihydrocucurbitacin $\mathrm{B} / 100 \mathrm{~g}$ plant drug and $2.32 \pm 0.04 \mathrm{mg}$ cucurbitacin B/100 g plant drug (Figure 1).

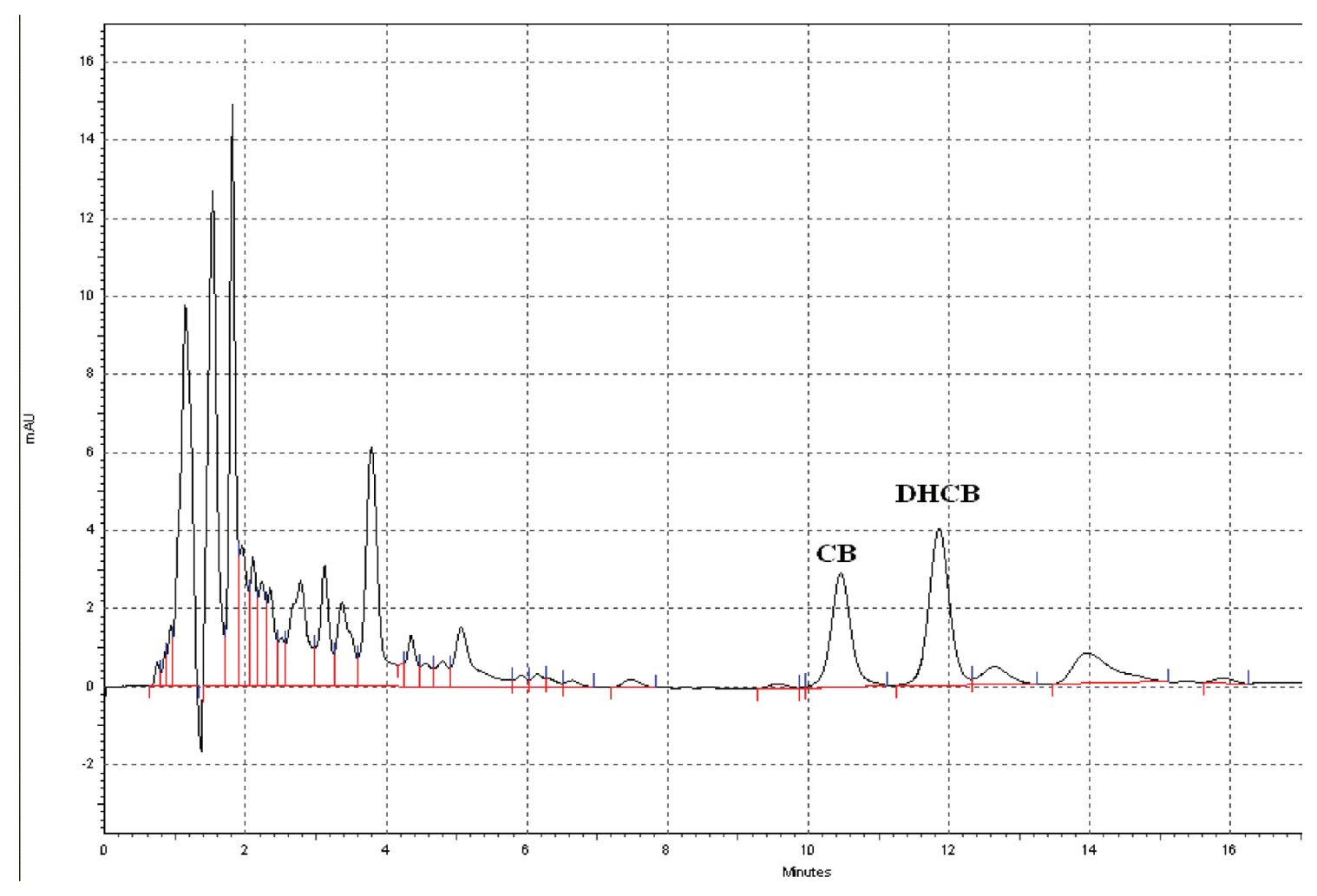

Figure 1. Chromatogram of Wilbrandia ebracteata root extract. Peaks corresponding to cucurbitacin B (CB) and dihydrocucurbitacin $\mathrm{B}$ (DHCB). 
The results of the annual analysis demonstrated that the concentration of cucurbitacin B, a cytotoxic compound at high concentration, was higher in 2003, and the relation dihydrocucurbitacin B/cucurbitacin B was reduced. This fact can be explained by herbivore attack to the root since it was observed that the root was damaged at the moment of the harvest. Others authors have studied this kind of effect on Cucurbita species (Cucurbitaceae). It was found that even small levels of tissue injury cause very rapid rising of the concentration of cucurbitacin B on leaves (Tallamy \& McCloud, 1992).

Table 1. Concentration of cucurbitacin B (CB) and dihydrocucurbitacin B (DHCB) in the root of Wilbrandia ebracteata collected on four years.

\begin{tabular}{cccc}
\hline Year & CB $(\mathrm{mg} / 100 \mathrm{~g})$ & $\mathrm{DHCB}(\mathrm{mg} / 100 \mathrm{~g})$ & $\mathrm{DHCB} / \mathrm{CB}$ \\
\hline 2002 & $2.27 \pm 0.07$ & $42.5 \pm 0.6$ & 18.7 \\
2003 & $38.7 \pm 1.1$ & $65.9 \pm 0.7$ & 1.70 \\
2004 & $8.73 \pm 0.24$ & $45.0 \pm 0.9$ & 5.15 \\
2005 & $2.35 \pm 0.02$ & $45.2 \pm 0.9$ & 19.2 \\
\hline
\end{tabular}

HPLC method for the analysis of W. ebracteata roots has been developed allowing the quantification of dihydrocucurbitacin B and cucurbitacin B. The method was found to be precise and accurate.

In conclusion, this method of quantification becomes a reference for the quality control of products based cucurbitacins, thus guaranteeing the security and efficacy of the finished product.

\section{ACKNOWLEDGEMENTS}

The authors gratefully acknowledge Prof. Dr. Eloir Paulo Schenkel for the vegetable material harvesting in Nova Petrópolis-RS, Brazil. This study was supported by grants from the Conselho National de Desenvolvimento Científico e Tecnológico (CNPq) and Coordenação de Aperfeiçoamento de Pessoal de Nível Superior (CAPES).

\section{REFERENCES}

Bauer R, Berganza LH, Seligmann O, Wagner H 1985. Cucurbitacins and flavone C-glycosides from Cayaponia tayuya. Phytochemistry 24: 1587-1591.

Brock ACK, Duarte MR, Nakashima T 2003. Morpho-anatomical study and phytochemical screening of fruits and seeds of Luffa operculata (L.) Cogn. Cucurbitaceae. Vis Acad 4: 31-37.

Farias MR, Schenkel EP, Mayer R, Rücker G 1993. Cucurbitacins as constituents of Wilbrandia ebracteata. Planta Med 59: 272-275.

Corrêa PM 1984. Dicionário d e plantas úteis do Brasil e das exóticas cultivadas. Rio de Janeiro: Ministério da Agricultura, IBDF.

González FG, Di Stasi LC 2002. Anti-ulcerogenic activities of the leaves of Wilbrandia ebracteata in mice. Phytomedicine 9: 125-134.

Halaweish FT, Tallamy DW 1993. Quantitative determination of cucurbitacins by high performance liquid chromatography and high performance thin layer chromatography. J Liq Chromatogr 16: 497-511.

International Conference on Harmonisation (ICH). Validation of Analytical Procedures: Methodology. 1996.

Matsuo K, Demilo AB, Schroder RFW, Martin PAW 1999. Rapid high performance liquid chromatography method to quantitate elaterinide in juice and reconstituted residues from a bitter mutant of Hawkesbury watermelon. J Agric Food Chem 47: 2755-2759.

Oliveira F, Akissue G, Akissue MK 1991. Farmacognosia. São Paulo: Atheneu.

Pavan FR, Sato DN, Higuchi CT, Santos ACB, Vilegas W, Leite CQE 2009. In vitro anti-Mycobacterium tuberculosis activity of some Brazilian "Cerrado" plants. Rev Bras Farmacogn 19: 204-206.

Peters RR, Farias MR, Ribeiro-Do-Valle RM 1997. Antiinflammatory and analgesic effects of cucurbitacins from Wilbrandia ebracteata. Planta Med 63: 525-528.

Peters RR, Saleh TF, Lora M, Patry C, Brum-Fernandes AJ, Farias MR, Ribeiro-Do-Valle RM 1999. Anti-inflammatory effects of the products from Wilbrandia ebracteata on carregeenan-induced pleurisy in mice. Life Sci 64: 24292437.

Peters RR, Krepsky PB, Siqueira-Junior JM, Rocha JCS, Bezerra MM, Ribeiro RA, Saleh TF, Brum-Fernandes AJ, Farias MR, Rocha FACR, Ribeiro-Do-Valle RM 2003. Nitric oxide and ciclooxygenase may participate in the analgesic and anti-inflammatory effect of the cucurbitacins fraction from Wilbrandia ebracteata. Life Sci 73: 2185-2197.

Schenkel EP, Farias MR, Mayer R, Breitmaier E, Rücker G 1992. Cucurbitacins from Wilbrandia ebracteata. Phytochemistry 31: 1329-1333.

Simões CMO, Mentz LA, Schenkel EP, Irgang BE, Stehmann JR 1996. Plantas da Medicina Popular do Rio Grande do Sul. Porto Alegre: Editora da UFRGS.

Siqueira Jr JM, Peters RR, Gazola AC, Krepsky PB, Farias MR, Era GA, Brum-Fernandes AJ, Ribeiro-do-Valle RM 2007. Anti-inflammatory effects of a triterpenoid isolated from Wilbrandia ebracteata Cogn. Life Sci 80: 1382-7.

Stuppner H, Wagner H 1992. TLC and HPLC analysis of iridoid, cucurbitacin and phenol glycosides from Picrorrhiza kurroa. Sci Pharm 60: 73-85.

Sturm S, Stuppner H 2000. Analysis of cucurbitacins in medicinal plants by high-pressure liquid chromatography-mass spectrometry. Phytochem Anal 11: 121-127.

Tallamy DW, McCloud ES 1992. Squash beetles, cucumber beetles, and inducible cucurbit responses. In: Rosenthal GA, Rerenbaum MR (ed.) Herbivores: their interactions with secondary plant metabolites. London: Academic Press, p.155-181.

United States Pharmacopeia 1995. The National Formulary (NF18). Rock-ville: United States Pharmacopeial Convention, p.1806-1812. 